\title{
MENYEMBUHKAN LUKA BATIN DENGAN MEMAAFKAN
}

\author{
Christian Siregar \\ Jurusan Psikologi, Faculty of Humanities, BINUS University \\ Jln. Kemanggisan Ilir III No. 45, Kemanggisan - Palmerah, Jakarta Barat 11480
}

\begin{abstract}
ABSTRAK
Menyembuhkan luka batin dengan memaafkan adalah langkah yang sangat diperlukan untuk pemulihan diri seseorang sehingga ia dapat mengalami suasana hati yang damai sejahtera. Baik penderita (korban) maupun pelaku, keduanya-dalam rangka penyembuhan-perlu menyadari serta mengakui dengan jujur dan terbuka bahwa dirinya sesungguhnya menderita akibat luka batin yang tertanam dalam hati, yang bahkan dapat dialami seseorang sejak ia berada dalam kandungan, dan karena itu perlu segera mengambil tindakan memaafkan. Mengingat bahwa luka batin adalah masalah yang dapat dialami siapa saja dan mengakibatkan dampak negatif dalam kehidupan seseorang, maka penelitian ini dilakukan. Penelitian yang didasarkan atas tinjauan sejumlah literatur ini menunjukkan bahwa terdapat korelasi yang kuat antara luka batin yang diderita seseorang dengan pengalaman masa lalunya yang buruk. Penelitian juga memperlihatkan bahwa luka batin itu dapat disembuhkan dengan memaafkan. Penelitian ini diharapkan dapat menjadi sumbangsih bagi penyelesaian masalah luka batin yang disebabkan masa lalu seseorang dengan tindakan memaafkan.
\end{abstract}

Kata kunci: menyembuhkan, luka batin, memaafkan

\begin{abstract}
Healing the inner wounds by forgiveness is an indispensable step for the recovery of one's self so he/she can experience peace and prosperity. Both of patient (victim) and actors, they need to realize and to confess honestly and openly-in order to heal-that he/she was actually suffering from the inner wounds that are embedded in the heart, which can even be experienced by a person since he/she was in the womb, and therefore need to be take immediate action to forgive. Considering that inner wounds is a problem that can be experienced by anyone and the resulting negative impact in one's life, then the research was conducted. The study, based on a literature review indicates that there is a strong correlation between inner wounds suffered by a person with a bad past experiences. Research also shows that the inner wounds that can be healed by forgiveness. The study is expected to be contributing to problem solving inner wounds caused by a person's past by forgiveness.
\end{abstract}

Keywords: healing, inner wounds, forgiving 


\title{
PENDAHULUAN
}

Luka batin dapat dialami siapapun baik secara disadari atau tidak, bahkan luka batin yang sangat parah dapat dialami seseorang sejak ia masih berada dalam kandungan. Perilaku kasar orangtua yang tidak menghendaki kelahiran bayinya, yang diindikasikan dengan adanya sikap-sikap penolakan; antara lain, mengumbar rasa benci dengan kata-kata umpatan-baik yang diucapkan maupun tersimpan rapat dalam hati-yang ditujukan secara langsung atau tidak langsung pada si jabang bayi, upaya pengguguran kandungan dengan mengonsumsi obat-obatan secara berlebihan, perilaku kasar yang tidak jarang disertai tindak kekerasan terhadap bayi atau anak hingga masa tertentu; kesemuanya itu dipercaya dapat menyebabkan seseorang mengalami luka batin. Payne (1991) mengatakan bahwa korban tindak kekerasan pada usia anak kelak akan sering merasa sulit untuk menerima kenyataan bahwa orang tua mereka telah benar-benar melakukan sesuatu yang salah. Namun kenyataan bahwa orang-orang terdekat kerap menjadi pelaku tindak kekerasan yang mengakibatkan seseorang mengalami luka batin adalah fakta yang sulit disangkal.

Kasus yang terjadi pada David James (Dave) Pelzer, misalnya. Pelzer, kelahiran 29 Desember 1960 di Daly City, California, adalah seorang penulis Amerika. Ia menjadi salah seorang terpopuler di tahun 1995 karena memoarnya tentang pelecehan yang dialaminya pada masa kanak-kanak, A ChildCalled "It". Selain buku itu, Pelzer juga menulis dua buku lain yang memuat pengalaman pahit masa kecilnya dan refleksi atas perjalanan hidupnya, yaitu The Lost Boy dan A Man Named Dave. Dalam bukunya A ChildCalled "It", Pelzer—anak kedua dari lima bersaudara laki-lakimendeskripsikan dengan lugas bagaimana ia telah mengalami penyiksaan yang parah dalam tenggat waktu yang cukup lama (menahun) oleh salah seorang terdekat yakni ibunya sendiri, Catherine Roerva Christen Pelzer(1929-1992). Sebagai seorang anak, Pelzer terus disiksa, dianiaya dan dipukuli oleh ibunya, yang menganggap hal itu sebagai permainan. Dalam dokumen buku tersebut diungkapkan bagaimana tindakan ibunya yang pemabuk ketika Pelzer kelaparan, memaksanya untuk minum amonia, menusuknya di bagian perut, dibakar lengannya di atas kompor gas dan memaksanya untuk makan muntahannya sendiri.

Sedangkan dalam A Man Named Dave, Pelzer (2003: 151) menyaksikan,

\begin{abstract}
"Sebagai anak yang hidup dalam kegelapan, saya merasa takut seumur hidup dan saya kira hanya saya seorang diri saja yang hidup seperti itu. Kini, setelah dewasa, saya tahu bahwa saya bukan satu-satunya anak yang mengalami kehidupan seperti itu-ada ribuan anak lain korban penyiksaan. Ada beragam sumber informasi, tetapi diperkirakan satu dari lima anak mengalami penyiksaan fisik, emosional, dan seksual di negara kami (Amerika Serikat).”
\end{abstract}

Pengalaman masa kecil Dave Pelzer yang pahit dan sangat menyakitkan begitu membekas dan telah menimbulkan akibat serius yang harus ditanggungnya pada masa mendatang, setelah ia dewasa. Ada akibat jangka panjang dari pengalaman kekerasan di masa kanak-kanak setiap kali korban teringat atau mengingat peristiwa kekerasan yang dialami sebelumnya, ia kembali merasa terluka. Hal ini disebutkan dalam reportasi Sr. Maria Felicia (2010) dari Tim Carmelia (tim pendampingan bagi korban luka batin) mengenai pengalaman seorang gadis (NN). NN menceritakan keluh kesahnya. Dia seringkali diliputi perasaan cemas dan bersalah yang berlebihan (anxiety), setelah melakukan sesuatu yang kurang berkenan di hati orang lain. Sejujurnya, apa yang telah dilakukannya bukanlah menjadi alasan untuk itu. Jadi, sebenarnya dia terlalu sensitif untuk hal yang demikian, karena hanya sebuah kesalahan yang sangat kecil saja, dia harus "menghukum” dirinya sedemikian rupa. Teman-temannya sering kali mencoba meyakinkan NN bahwa perbuatan yang dilakukannya bukanlah suatu masalah. Akan tetapi, perasaan tersebut masih saja membebani NN. Dia menjadi sangat tersiksa sehingga takut bila mendapat suatu tanggungjawab yang cukup besar, karena dia takut mengecewakan orang yang memberikan tanggungjawab tersebut. Dengan demikian, NN harus berjuang untuk menyeimbangkan perasaan dan tanggungjawab yang dijalankannya. 
Setelah kasusnya didalami melalui suatu proses pendampingan dan percakapan konsultasipastoral yang ketat baru diketahui bahwa sebenarnya ada "sesuatu" di balik semua peristiwa yang dialami NN selama ini. Diketahui ternyata sewaktu dia berada di dalam kandungan, si ibu merasa takut hamil lagi, sementara anaknya masih kecil. Si bu sangat takut, orang tuanya yang sering turut campur di keluarganya menjadi marah akibat dia hamil lagi. Selama masa kehamilan, si ibu selalu diliputi rasa takut dan was-was. Dia selalu berusaha membuat hati orang tua dan mertuanya senang, supaya dia tidak dipersalahkan dengan kehamilannya itu. Apapun yang dia kerjakan, dibuatnya sesempurna mungkin supaya tidak ada alasan bagi mereka untuk memarahinya. Dia selalu mengorbankan diri sendiri, apapun akan dilakukan supaya tidak dipersalahkan atas kehamilan tersebut. Semuanya disimpan sendiri dengan rapinya hingga sang suami pun tidak mengetahui perjuangannya. Semuanya dilakukannya secara sempurna dan bila dipandang kurang sempurna dia akan merasa ketakutan, takut mendapat teguran yang pada akhirnya akan mempersalahkan tentang kehamilannya tersebut.

Pengalaman seperti di atas adalah beberapa dari sekian banyak pengalaman lain yang (mungkin) pernah dialami oleh banyak orang. Masih banyak lagi pengalaman-pengalaman negatif yang disebabkan oleh luka batin dan menyebabkan efek-efek yang tidak mengenakkan di masa sekarang. Tulisan berikut ini mencoba mengulas lebih jauh beberapa aspek dari luka batin, seperti mengenali lebih jauh penyebab luka batin, mengenali adanya (indikator) luka-luka batin, dan korelasinya dengan tindakan memaafkan (dari sisi korban) sebagai salah satu alternatif cara penyembuhan luka batin.

\section{Penyebab Luka Batin}

Sr. Maria Felicia (2010) mengatakan bahwa setiap manusia mempunyai alam bawah sadar. Alam bawah sadar, seperti komputer yang dapat merekam segala pengalaman dan peristiwa yang pernah dialami selama hidup di dunia ini, baik peristiwa atau pengalaman yang menyenangkan (positif) maupun yang menyakitkan (negatif).

Masa-masa yang rawan untuk luka batin menurutnya adalah:

\section{Masa dalam Kandungan}

Alam bawah sadar sudah dapat merekam sejak kita berada dalam kandungan. Jadi, apa yang dialami dan dirasakan oleh sang ibu, si janin sudah ikut merasakan dan apa yang dirasakan ini terekam dalam alam bawah sadarnya. Maka dari itu, apabila sang ibu yang sedang mengandung mendapatkan kasih sayang dari orang-orang di sekitarnya, ini akan mempengaruhi si bayi yang ada dalam kandungan. Demikian pula bila pada masa kehamilannya dia mendapatkan perlakuan yang kurang wajar ataupun kesedihan-kesedihan yang dialaminya, maka inipun akan sangat berpengaruh bagi si bayi. Lebih-lebih lagi, bila bayi dalam kandungan mendapat penolakan atau tidak dikehendaki dilahirkan atau malah pernah akan digugurkan tetapi tidak berhasil. Ini sangat-sangat berpengaruh pada si anak nantinya. Anak yang pada masa dalam kandungan mendapat penolakan seringkali mengakibatkan si anak menjadi pemberontak, penakut, marah tanpa alasan, dan lain sebagainya. Atau bila si ibu pada masa kehamilannya, dia mengalami tekanan, rasa kuatir dan putus asa, maka si anak juga akan membawa perasaan-perasaan yang dialami si ibu.

\section{Masa Kelahiran}

Saat kelahiran adalah saat-saat yang singkat tetapi pada saat-saat yang singkat itupun tidak luput dari bebasnya akar luka batin. Mungkin terjadi kelahiran yang sulit, dan bila terjadi demikian biasanya menjadikan si anak kurang percaya diri, takut tampil di muka umum, atau juga sering merasa bersalah. Atau kelahiran prematur, si anak akan sering merasa minder, tidak berdaya, dan selalu bergantung dengan orang lain. 


\section{Masa Bayi}

Bayi yang seringkali ditinggal oleh orang tuanya (karena kesibukan orang tua) dan diserahkan kepada pembantu, akan membuat si anak mencari perhatian dari orang lain, karena pada waktu bayi kurang perhatian dan kasih sayang sehingga nantinya akan mencari sesuatu yang kurang itu dalam diri orang lain.

\section{Masa Kanak-kanak}

Masa kanak-kanak juga menjadi masa yang rawan untuk luka batin. Sebagai contoh, cerita seorang gadis lagi yang semasa kecilnya seringkali mendengar dan menyaksikan pertengkaran orang tuanya. Ketika peristiwa tersebut terjadi, dia merasa sangat ketakutan dan sebagai anak-anak dia tidak dapat melakukan apa-apa untuk mencegah pertengkaran itu, yang bisa dia lakukan hanyalah menangis. Ternyata peristiwa ini sangat membekas dalam pikiran dan hatinya sehingga pada masa dewasa, bila dia mendengar suatu keributan-keributan dia akan merasa sangat ketakutan dan tak jarang dia akan menangis bila mendengar keributan itu. Akan tetapi, setelah penyembuhan batin dengan mengampuni kedua orang tua dan melupakan peristiwa tersebut, maka dia dilepaskan dari ketakutannya.

\section{Masa Remaja atau Dewasa}

Masa remaja ataupun masa dewasa (sekarang) pun juga masih dapat menjadi akar dari luka batin. Misalnya seorang yang pernah dilecehkan atau pernah diperkosa. Trauma dan peristiwa yang menyakitkan itu akan sangat membekas dan bisa membuat dia antipati dengan lawan jenis sehingga dia menjadi takut menikah.

\section{Mengenali Adanya Luka-Luka Batin}

Sr. Theresianne Sasraningrat (2006) mengatakan ada simtom-simtom yang dapat dijadikan acuan untuk mengenali adanya luka-luka batin pada diri seseorang.

\section{Pemicu yang membangkitkan simtom-simtom:}

Pemicu yang membangkitkan simtom-simtom yang menunjukkan adanya luka-luka batin. Pemicu-pemicu itu antara lain: (a) Peristiwa yang membangkitkan rekaman-rekaman pengalaman keterlukaan, seperti: Hujan yang membangkitkan pengalaman traumatik dengan pusaran air yang mencekam, peristiwa kekerasan dan kekacauan yang membangkitkan rekaman pengalaman perang, penugasan dengan tanggung jawab untuk mengatur kerumahtanggaan suatu organisasi; (b) Orangorang, tempat, suasana (lagu, dekorasi ruang, pesta) yang membangkitkan rekaman pengalamanpengalaman keterlukaan, seperti antara lain sosok tertentu, gaya, suara, pakaian, sepatu yang dipakai seseorang bisa membangkitkan rekaman tentang pribadi yang menyebabkan terjadinya luka batin karena sosok dan atau gaya tersebut mirip dengan sosok dan atau gaya penyebab luka batin; karena suara tersebut mirip dengan suara pribadi yang menyebabkan terjadinya luka batin; karena pakaian dan sepatu tersebut mirip dengan pakaian dan sepatu yang dipakai pribadi penyebab terjadinya luka batin seseorang. Selain itu, tempat juga suasana yang mempunyai kemiripan dengan tempat atau suasana saat luka batin dibangkitkan; misalnya, seseorang yang menghindari bertemu dengan sinterklas pada musim natal karena waktu kecilnya, ia sering ditakut-takuti (kalau nakal) akan dimasukkan dalam karung swarte Piet (Piet hitam).

\section{Simtom yang Menunjukkan Adanya Luka-Luka Batin}

Simtom adalah reaksi-reaksi terhadap pemicu, dalam bentuk yang tidak proporsional. Simtom terindikasi pada seseorang manakala misalnya, orang tersebut tiba-tiba merasa seperti orang yang ditinggal, tiba-tiba marah (yang mungkin tidak ditunjukkan) pada seseorang, tiba-tiba ingin menyakitkan hati (victimizing) seseorang dengan menjebak, membohongi, mempermalukan di muka 
umum, dan lain sebagainya; bersikap defensif, berbicara dengan suara yang semakin meninggi; malu, suara bergetar dalam berbicara; iri hati, senang menyebarkan gosip (kabar bohong) atau fitnah, dan lain sebagainya.

\section{Kapan simtom-simtom itu muncul?}

Ia sudah muncul tanpa disadari oleh pribadi yang bersangkutan. Pribadi yang bersangkutan akan menyadarinya sebagai simtom bila sudah tiba saatnya bagi dia untuk mengolahnya sampai selesai. Tetapi belum tentu pribadi yang bersangkutan bersedia mengolahnya.

\section{Sikap-Sikap Dasar yang Diperlukan dalam Penyembuhan Luka Batin}

Dalam menjelaskan sikap-sikap dasar yang diperlukan seseorang untuk penyembuhan luka batinnya, baik Sr. Theresianne Sasraningrat (2006) maupun Sr. Maria Felicia (2010) sependapat, bila seseorang mau berhasil dalam melangsungkan kesembuhan luka batinnya, ia perlu memiliki atau menghidupi sikap-sikap dasar yang penting, seperti kemauan untuk mengenali keberadaan diri, keterbukaan terhadap realita yang ada dalam batinnya, kerinduan akan kebenaran mengenai dirinya sendiri, kerendahan hati untuk menerima keberadaan diri, determinasi (tekad) untuk bertumbuhkembang dan untuk sembuh dari keterlukaan-keterlukaan batin, semangat untuk mengampuni orang yang telah melukai hatinya, mengecewakannya dan membencinya (sebab perlu diingat bahwa pengampunan pertama-tama adalah soal keputusan dan bukan perasaan), dan bila ada dosa maka sepatutnya memiliki keinginan untuk bertobat dan melakukan pertobatan terlebih dahulu, serta memiliki iman-meski kadang-kadang hal ini tidak bersifat mutlak atau dapat dimutlakkan (karena faktanya belum tentu semua orang beriman atau beragama).

\section{Metode Penyembuhan Luka Batin dengan Pengampunan}

Ada banyak cara atau metode yang ditawarkan dan dapat digunakan sebagai kiat-kiat untuk penyembuhan luka-luka batin seseorang seperti lokakarya-lokakarya berkelanjutan, pendampingan pribadi atau kelompok, pembuatan jurnal-jurnal pribadi, program retret atau pesantren kilat dan sebagainya. Namun sebagaimana sudah penulis sebutkan di bagian pengantar/pendahuluan makalah ini, penulis akan membatasi diri pada aspek pengampunan (memaafkan) — terutama dari sisi korban— dalam metode penyembuhan luka batin.

Ignatius Sunandar (2010) dalam testimoni (kesaksian) pribadinya mengungkapkan:

Saya sedang bersama Pastor Ketua Badan Kerjasama Sekolah (BKS) YPK Kevikepan Surakarta mempersiapkan LPJ pengurus BKS periode 2007-2009, di ruang pertemuan kantor Yayasan Kanisius Cabang Surakarta, ketika Hp saya bergetar menandakan ada SMS masuk. Sejenak tergetar perasaan saya saat mengetahui bahwa pengirimnya adalah seseorang yang pernah menorehkan lukisan indah tentang kehidupan dalam kanvas sejarah hidup saya. Bulan Maret sepuluh tahun yang lalu saya memberitakan sesuatu yang meretakkan bejana hatinya dan mengoyakkan hubungan saya dan dia. Amat singkat saya menulis pesan via email kepadanya, "I'm a married man.” "Saya sudah menikah.” Kata-kata itu telah cukup lama saya simpan sejak saya menikah setahun sebelumnya. Cinta mati yang pernah saya ikrarkan padanya tiba-tiba menjadi tusukan tajam tepat pada pusat harga dirinya. Saya tidak bisa membayangkan apa persisnya yang terjadi setelah itu berita itu.

Saya sudah sangat lama menanti ungkapan yang ada dalam pesan singkat itu, forgiving, memaafkan. Bukan pertama-tama menunggu saya dimaafkan tapi lebih menanti dia memaafkan karena saya percaya Tuhan telah memaafkan saya dan saya juga telah memaafkan diri saya sendiri. Menjelang hari Rabu Abu 2010, dia mengatakan bahwa dia memaafkan saya dan memaafkan dirinya sendiri meski hatinya masih terluka. Tentu saja bekas luka itu akan tetap menghiasi bejana hidupnya. Baginya, memaafkan merupakan suatu proses perjuangan. Saya memahami itu. 
Pengalaman bersama dia memberikan pelajaran mendasar bagi saya tentang mencintai, tentang luka hati, tentang sakit, tentang memaafkan, tentang kesetiaan dan tentang hidup yang lainnya. Kali ini saya akan bicara tentang memaafkan yang membebaskan belenggu luka-luka hati yang menimbulkan kepedihan dan kesakitan itu.

Rasa sakit sesakit-sakitnya melampaui rasa sakit fisik yang pernah saya alami adalah ketika saya menyadari telah menyakiti orang yang sangat saya cintai. Seluruh jiwa dan raga saya benar-benar merasakan sakit itu. Sakit dalam jiwa saya sampai berimbas pada tubuh saya yang kadang menggigil, bergetar. Keinginan paling kuat adalah keinginan untuk mati. Saya benarbenar menderita karena beban batin yang sangat berat, menyesakkan, memalukan, menghancurkan semua bangunan kepercayaan diri dan juga bangunan kesombongan saya. Pada saat bersamaan saya telah menghancurkan hubungan saya dengan orang tua saya, dengan lembaga yang membesarkan saya, dengan orang-orang yang saya cintai dan yang paling menusuk pusat keberadaan saya sebagai seorang pribadi manusia adalah karena saya telah mengkhianati orang yang paling saya cintai.

Selama tiga bulan saya bergulat dengan kehancuran diri. Secara alamiah selama bergulat itu, saya membangun kekuatan untuk menghadapi semuanya dengan memohon campur tangan pemberi hidup saya. Keinginan yang begitu kuat untuk mati karena tidak kuat menanggung beban psikis dan rasa sakit jiwa itu membawa saya pada titik di mana saya tidak lagi takut merasakan rasa sakit fisik. Sakit fisik akan otomatis berhenti bila ambang batas rasa sakit itu telah terlampaui dan orang akan pingsan. Saya merasa bahwa saya sebenarnya sudah mati, sudah habis, sudah tak berharga lagi di mata dunia ini. Saya telah menghancurkan bangunan hidup saya sendiri. Beruntung bahwa saya tidak sampai menjadi gila karena baban psikis itu. Allah yang telah menciptakan saya turun tangan. Saya dihidupkan lagi. Bejana hidup saya yang sudah hancur berantakan disatukan lagi. Dia mengatakan kepadaku, "Engkau berharga di mata-Ku."

Moment itu merubah total cara pandang saya terhadap apa yang saya alami dan terhadap kebodohan yang menghasilkan penderitaan bagi diri saya. Saya menderita karena kebodohan saya sendiri dan saya merasa sudah tidak layak lagi hidup di hadapan manusia mana pun di dunia ini. Tetapi, Tuhan melihatnya dengan cara lain. Di hadapan-Nya saya tetaplah manusia yang Dia cintai. Saya serahkan secara total hidup saya, jalan hidup saya kepada-Nya. Itu adalah saat saya merasakan bagaimana berserah diri total kepada Allah yang membebaskan saya. Saya merasa terangkat, saya merasa bahwa hidup saya sebenarnya tidak sia-sia. Saya melihat terang lagi. Sehancur-hancurnya hidup saya bukankah saya masih tetap hidup? Dan saya diciptakan bukan tanpa tujuan. Maka saya hidup lagi.

Sejak itu pula saya tidak takut mati. Tidak takut kehilangan. Tidak takut merasakan sakit fisik karena bila sudah melampaui ambang batas daya tahan pasti saya akan pingsan dan dengan demikian saya selamat. Yang harus saya lakukan terus-menerus adalah memaafkan diri sendiri. Tentu saja saya minta maaf kepada semua pihak yang telah saya sakiti. Entah mereka sudah memaafkan saya atau belum saya tetap yakin bahwa Allah telah memaafkan saya. Memaafkan diri itu juga tidak seketika selesai. Saya semakin yakin bahwa untuk bisa membebaskan diri saya sendiri dari rasa bersalah adalah dengan memaafkan, tidak ada cara lain. Dan memaafkan itu merupakan jalan penyembuhan. Saya tidak tahu persis apa yang dialami oleh orang yang telah saya lukai. Saya hanya bisa menduga bahwa tentu amat sakit dikianati oleh orang yang paling dia cintai. Saya hanya tahu bahwa dia sangat terluka dan tidak segera bisa memaafkan saya. Kiranya Dia yang dulu menghidupkan saya lagi telah turun tangan atau lebih tepatnya dia telah memberi kesempatan pada-Nya untuk turun tangan. Saya berharap, dengan memaafkan saya, dia akan sembuh dari sakitnya dan ada damai di dalam hatinya.

Dengan contoh pengalaman seperti yang diceritakan di atas, dapat diketahui bahwa efek dari luka batin selain mempersulit dan mempengaruhi dalam kehidupan bersama orang lain, juga yang paling dapat dirasakan adalah hilangnya kedamaian dalam hati. Melalui penyembuhan luka batin maka kedamaian yang hilang itu akan dapat diperoleh kembali. Penyembuhan luka batin salah satunya dapat dilakukan dengan pemaafan. Dari sisi pelaku kejahatan berarti memaafkan (berdamai dengan) diri 
sendiri dan minta maaf kepada korban (serta pihak-pihak terkait). Dari sisi korban berarti memaafkan orang yang telah berbuat jahat dengan melukai batinnya.

Brandsma (1982) sebagaimana juga dikutip pendapatnya oleh Mawan (2009) mendefinisikan pengampunan sebagai penguasaan terhadap pikiran-pikiran, perasaan-perasaan dan tingkah laku yang negatif; tanpa mengabaikan yang terluka atau marah, tetapi memandang orang yang melakukan kesalahan dengan penuh penerimaan sehingga si pemberi ampun dapat disembuhkan. Sedangkan Augsburger (1981) sebagaimana dikutip juga pendapatnya oleh Mawan (2009) mendefinisikan pengampunan sebagai penerimaan tanpa syarat. Pengampunan tidak saja berarti menerima kesedihan hati yang seseorang rasakan, tetapi juga menerima orang yang sudah melakukannya dan menerima kerugian yang disebabkan oleh tindakan atau perkataan yang menyakitkan. Dengan demikian pengampunan atau pemaafan dapat didefinisikan sebagai proses coping individu yang dapat menerima dan mengatasi emosi negatif seperti rasa marah, benci, sakit hati, dan menggantinya dengan keinginan yang kuat untuk mencari sesuatu yang bermakna, seperti misalnya kedamaian hati.

Ahli lain, McCullough dkk. (1997: 321) menjelaskan memaafkan antarpribadi sebagai "transformasi motivasi yang mengarahkan orang untuk berperilaku konstruktif terhadap seseorang yang telah berperilaku destruktif terhadap mereka". Worthington (1998: 108) menjelaskan pengampunan sebagai "motivasi untuk mengurangi upaya menghindar dan menarik diri dari seseorang yang telah menyakiti kita, serta kemarahan, keinginan untuk membalas dendam, dan dorongan untuk membalas sakit hati terhadap orang lain". Sementara Enright dkk. (1991: 140) mendefinisikan pengampunan "sebagai kemauan seseorang untuk meninggalkan haknya mengumbar kebencian, penilaian negatif dan perilaku acuh tak acuh terhadap orang yang telah bertindak melukai hatinya dengan tidak adil, sementara ia mengembangkan sifat tidak seharusnya berbelas kasih, bermurah hati bahkan cinta terhadap orang itu". Dengan perkataan lain, memaafkan dalam perspektif para ahli adalah suatu kehendak yang kuat dalam diri seseorang (korban) untuk melepaskan penilaian yang negatif terhadap pelaku kejahatan yang telah melukainya, dan menggantinya dengan keinginan untuk berbelas kasih terhadap pelaku kejahatan tersebut.

Menurut Worthington (1998: 80, 1999) pemaafan terbagi dalam dua dimensi. Pertama, dimensi intrapsikis, yang melibatkan empati (emotion state) dan ditandai dengan hilangnya emosi negatif dari dalam diri individu yang menjadi korban. Kedua, dimensi interpersonal, yang ditandai dengan kemampuan individu bertemu kembali dengan orang yang telah melukainya, dan menerimanya sebagaimana saat sebelum peristiwa yang menyakitkan (transgression) itu terjadi.

Menurut Pargament (1997) pemaafan yang demikian terjadi karena korban melakukan religious coping. Agama yang di dalamnya mengajarkan nilai-nilai yang baik, seperti mengampuni, mampu menjadikan individu menahan diri dari membalas dan berbuat kejahatan.

\section{Mengapa Memaafkan?}

Terhadap para pelaku kejahatan yang telah menyakiti korban, Fitzgibbon-Hope (1986) dan Worthington (1997) menyatakan bahwa korban dapat saja memilih bersikap marah dan tidak mau memaafkan, tetapi korban juga harus mempertimbangkan risiko yang diakibatkannya. Risiko tersebut dapat berupa antara lain, gangguan emosi, rusaknya hubungan antar pribadi (interpersonal), dan dapat juga terjadi gangguan fisik yang berwujud gangguan kesehatan. Sementara Enright dan Coyle (dalam Worthington: 1998) menemukan bahwa korban yang cenderung mempertahankan kemarahannya, sebenarnya secara diam-diam sedang membuat dirinya menderita. Dalam sikap tidak memberi maaf ini korban dihadapkan pada dua pilihan kemungkinan, yaitu: (1) Mempertahankan kemarahannya secara diam-diam, dan ini membuat dirinya menderita sampai dengan saat ia membalas pelaku dengan tindakan tertentu, atau; (2) Mengubah dirinya dengan cara memaafkan pelaku dan berusaha mengakhiri semua perasaan marah, benci, dan keinginan membalas serta menggantinya dengan emosi positif. 
Dengan demikian dalam setiap kesempatan terbuka pilihan bagi seorang korban untuk memaafkan pelaku yang telah menyakitinya, atau dengan perkataan lain, korban dapat bertahan pada pilihan sikap tidak memaafkan dan dapat juga mengubah pilihan sikap tersebut. Yang jelas, apabila korban memilih untuk memaafkan maka kedamaian hati yang akan didapatnya; sebagaimana diyakini betul oleh Ignatius Sunandar dalam contoh kasus di atas, dan disaksikan-berdasarkan pengalaman pribadioleh Dave Pelzer dalam buku-bukunya.

\section{Langkah-Langkah Memaafkan}

Mawan (2009) dalam perspektif teologis menguraikan tiga tahapan dalam proses mengampuni, yaitu:

\section{Mengingat Kembali Pengalaman Terluka}

Ini merupakan langkah yang paling sulit karena harus mengalami luka itu kembali. Memang kita telah belajar untuk mengabaikan, mengingkari, menerima luka; dan bahkan meneruskan luka ini kepada generasi berikutnya. Kalau kita tidak mau melakukannya maka kita akan tetap terikat dengan luka masa lalu dan kita tidak percaya kita mampu untuk bebas dari dampak luka yang dialami. Kita perlu untuk melepaskan segala macam bentuk pertahanan yang digunakan untuk menutup perasaan tersebut. Akibatnya akan timbul perasaan berduka. Dengan berduka akan membuat kita tidak lagi menyangkal dan menolak luka yang dialami dan membiarkan kita mengalami dan berusaha pulih melalui perasaan tersebut. Berduka dapat menjadi respon yang menyembuhkan bagi luka batin.

\section{Mengartikan / Memaknai Ulang Luka}

Ketika seseorang mengalami luka batin maka ia dapat menggunakan pikiran untuk merespon perasaan tersebut. Pikiran dapat dipakai menjadi bagian dari perlindungan diri dan membuat suatu strategi untuk dapat mengatasi luka batin dari pengalaman yang tidak menyenangkan tersebut. Setelah kita mengakui semua hal yang terjadi dan melihat luka batin dengan pikiran yang benar.

Harus diakui bahwa luka batin telah mengacaukan penilaian kita terhadap orang yang melukai dan diri kita yang dilukai. Kita menilai dia sebagai seorang penjahat dan diri kita sebagai korban. Namun, kita perlu menyadari bahwa Tuhan telah memberikan pikiran, kehendak dan emosi. Kehendak akan mengontrol pikiran dan pikiran akan mengontrol bagaimana kita beremosi. Dengan demikian kita perlu mengubah pikiran kita mengenai hal tersebut. Sehingga ketika kita mempunyai persepsi yang salah terhadap mereka maka kita perlu menyadari bahwa seringkali kita melihatnya dengan kacamaata luka batin kita. Kita tidak dapat memahami apa yang menjadi motivasi mereka. Dengan mengontrol pikiran kita maka kita dapat melihat bahwa mereka pun sama dengan kita: mereka pun sama-sama lemah. Kita seharusnya memandang mereka terpisah dari apa yang telah mereka perbuat dan memandang diri kita sendiri lebih dari luka yang kita derita. Ketika kita memandang diri kita sendiri sebagai pribadi maka kita mulai dapat meredakan kebencian kita. Ketika kita memandang diri kita lebih daripada luka yang kita derita maka kita dapat mengenal dengan lebih baik orang yang telah melukai.

\section{Melepaskan Rasa Marah}

Kita bisa terlepas dari kemarahan dengan cara mengakui adanya kemarahan itu dan membukanya. Kita menyadari bahwa kemarahan merupakan perasaan yang tidak menyenangkan bagi semua orang dan dapat membawa dampak yang buruk bagi oran lain. Kita perlu mengakui bahwa kita sering marah. Mengakui kepada diri sendiri, kepada orang yang sudah kita lukai karena sikap permusuhan kita dan mengakui kepada Tuhan. Mengakui kepada Tuhan adalah langkah awal untuk memperoleh kekuatan untuk memperoleh kekuatan untuk dapat melepaskan kemarahan dengan benar. Melepaskan kemarahan dengan benar berarti kita membuat diri kita sendiri secara sukarela tidak lagi 
mempunyai hak untuk membalas dendam. Ini berarti kita mengampuni atas apa yang telah mereka perbuat. Orang yang tidak melakukan pengampunan berarti orang tersebut akan terus mengalami luka emosional.

Sementara Worthington (1998) sebagaimana dikutip juga pendapatnya oleh Schimmel (2002) berdasarkan hasil penelitiannya tentang proses memaafkan dan juga pengalaman pribadinya dalam memaafkan terhadap pelaku pembunuhan ibunya telah menyusun model piramida REACH. R E A C $\mathrm{H}$ merupakan singkatan dari huruf depan pada tahapan-tahapan dalam proses memaafkan, yaitu:

\section{Recall The Hurt (Mengingat Ulang Luka)}

Sebagai langkah pertama, korban diminta untuk mengingat kembali pengalaman yang menyakitkan. Korban diminta untuk berbicara tentang luka batin yang dialaminya, dan ia dibantu agar sedapat mungkin mampu mengendalikan diri. Hal ini bisa dilakukan antara lain dengan meminta korban menuliskan sebuah surat yang berisi penjelasan tentang alasan dan motif pelaku melakukan transgression tersebut. Langkah ini diambil untuk mengingatkan korban kepada kepahitan yang telah dialaminya.

\section{Empathize with the One Who Committed the Hurt (Berempati)}

Langkah kedua, merupakan upaya untuk mengajak korban memikirkan apa yang dirasakan pelaku kejahatan setelah ia berbuat atau setelah transgression itu terjadi. Korban diajak untuk memikirkan dan menuliskan berbagai kemungkinan yang menurutnya dirasakan oleh si pelaku kejahatan. Selain itu korban juga diajak mengingat kembali interaksi yang ada dengan pelakumelalui berbagai pengalaman yang menyenangkan—sebelum transgression itu terjadi.

\section{Offer the Altruistic Gift of Forgiveness (Pentingnya Memberi Maaf Demi Mengutamakan Orang Lain)}

Selanjutnya, setelah korban mampu berempati, korban diminta mengingat berbagai pengalaman lain — bukan tentang transgression tersebut—saat ia merasa bersalah karena tidak memberi maaf ataupun saat ia kecewa dan kehilangan kesempatan untuk memaafkan. Dengan perkataan lain, korban diminta untuk menceritakan pengalamannya memberi maaf atau memaafkan berbagai hal di masa lalu, dan mengingat apa yang ia rasakan setelah memberi maaf tersebut. Lalu korban diminta untuk membayangkan bahwa memberi maaf adalah sebuah hadiah yang luar biasa bagi si pelaku transgression tersebut.

\section{Make A Commitment to Forgive (Komitmen untuk Memaafkan)}

Biasanya pemberian maaf itu terjadi di dalam diri (internal), namun akan lebih baik bila komitmen untuk memaafkan itu diungkapkan secara terbuka, (bila perlu) disaksikan juga oleh orang lain. Hal ini berguna untuk membantu korban dan memperteguh pemaafan yang telah ia berikan.

\section{Hold on to Forgiveness (Memegang Teguh Pemaafan)}

Langkah terakhir dalam proses memaafkan ini adalah mempertahankan komitmen yang telah dibuat. Langkah ini penting karena harus diakui bahwa emosi negatif dan perasaan terluka bisa muncul kembali, dan bila saat itu datang maka korban perlu bertindak untuk mengelola emosinya. Emosi korban perlu dikendalikan sedemikian rupa, sehingga tidak lagi dikuasai oleh emosi negatif yang memungkinkan korban menarik kembali maaf yang telah ia berikan.

Worthington (dalam Schimmel: 2002) menyatakan bahwa ia merumuskan konsep piramida REACH karena ia mengasumsikan adanya kondisi neurobiologis yang membuat seseorang belum siap 
untuk memaafkan, yaitu korban dihantui dan dikendalikan oleh pengalaman masa lalu dengan berbagai emosi negatif. Hanya jika setelah seseorang itu mampu menggabungkan emosi negatifnya dengan emosi positif atau dengan perkataan lain, mencoba merekondisi ulang bahkan berempati terhadap pelaku kejahatan, ia mulai mampu memaafkan.

\section{Faktor-Faktor yang Memungkinkan Pemaafan Terjadi}

Worthington (1998) dan McCullough (2000) menyebutkan empat elemen penting dalam pemaafaan. Dalam penanganan kasus-kasus luka batin-khususnya dalam sesi-sesi percakapan pastoral - upaya ke arah pemaafan perlu difasilitasi dengan membantu klien fokus pada empat faktor pemersatu penting, yakni: empati, kerendahan hati, komitmen, dan permintaan maaf. Selanjutnya Worthington (1998) — berdasarkan pengalaman pribadi dan hasil penelitiannya-menganalisis dan mendapati temuan bahwa hal yang paling berperan penting serta menentukan bagi terjadinya pemaafan adalah kemampuan berempati. Pendapat yang sama juga dikemukakan oleh para ahli lainnya bahwa empati merupakan faktor utama yang dalam proses pengampunan (lihat juga Coyle \& Enright, 1997; McCullough et al, 1997; Spring, 2004). Ada tiga jenis empati menurut Worthington (dalam Schimmel 2002), yaitu:

Pertama, Empati akurasi (empathic accuracy). Adalah empati yang muncul setelah korban mencari tahu dengan pasti duduk persoalan atau peristiwa yang sesungguhnya terjadi tentang apa yang dipikirkan dan dirasakan pelaku kejahatan, saat peristiwa yang menyakitkan itu terjadi. Kedua, Empati identifikasi (empathic identification). Adalah kesanggupan untuk berbagi (share) dengan orang lain yang mempunyai keadaan mental dan emosional yang serupa. Dengan cara berbagi ini maka ia akan merasakan ada orang lain dan bukan hanya dirinya sendiri yang terluka, bahkan mungkin derita batin orang lain itu dianggap lebih berat. Ketiga, Empati rasa iba / belas kasih (empathic compassion). Adalah perasaan haru terhadap pelaku kejahatan. Inilah yang menjadi tujuan dan langkah E dari proses pemaafan dalam piramida REACH.

McCoullough (2001) dari hasil penelitiannya menemukan bukti bahwa beberapa sifat (traits) kepribadian, misalnya empati dan suka menyenangkan orang (empathy and agreeable people), kestabilan emosi serta tingginya tingkat spiritualitas dan keagamaan seseorang mempengaruhi terjadinya pemaafan. Lebih jauh McCoullough mengemukakan tiga faktor yang menentukan sehingga seseorang dapat mengambil sikap memberi maaf, yaitu: Pertama, empati (didefinisikan sebagai $a$ specific emotion state) sangat berkorelasi kuat dan berpengaruh sehingga korban dapat memberi maaf pada pelaku kejahatan yang menyakitinya secara khusus dalam peristiwa yang spesifik. Kedua, atribusi kemurahatian (generous attribution) dan adanya pengetahuan yang cukup baik tentang peristiwa kejahatan serta pengenalan terhadap si pelaku kejahatan, dapat membuat seorang korban memberi maaf. Dengan perkataan lain, demikian dikatakan Shapiro (1991), penjelasan tentang transgression tersebut harus lebih lengkap dan dalam hal ini dibutuhkan kejujuran. Ketiga, perenungan kembali secara mendalam (rumination about the transgression). Perenungan ini baru mungkin dilakukan setelah seorang korban mampu melihat efek sebab akibat (mengatribusikan) dan membuat penilaian, baru kemudian memilih untuk memaafkan pelaku kejahatan itu.

\section{SIMPULAN}

Luka batin yang terus dibiarkan akan menjadi borok yang semakin menganga dan membuat orang yang mengalaminya merasakan sakit yang luar biasa. Kunci untuk menyembuhkan luka batin itu salah satunya adalah dengan memaafkan orang yang telah berbuat jahat. Tindakan memaafkan pada dasarnya akan lebih mudah dilakukan seseorang yang memiliki spiritualitas. Dengan perkataan lain, tindakan memaafkan merupakan cerminan spiritualitas seseorang atau spiritualitas seseorang, salah 
satunya, tercermin dari kesediaan dan kemampuannya memaafkan orang lain yang telah berbuat jahat dan melukai batinnya. Memaafkan memang bukan perkara yang mudah untuk dilakukan. Diperlukan kesediaan membuka diri untuk mengakui dengan jujur bahwa kita sedang mengalami luka batin, kesediaan untuk membuang emosi negatif dan menelaah kembali luka batin itu serta faktor-faktor yang menyebabkan dan atau mempengaruhinya, juga kemampuan untuk berempati dengan si pelaku kejahatan yang telah menorehkan luka batin itu, di samping itu juga sangat penting kemauan untuk sembuh. Meskipun tidak mudah tidak berarti pula bahwa penyembuhan luka batin dengan pemaafan adalah hal yang mustahil dilakukan. Sulit ya, tetapi mustahil tidak. Yang terpenting adalah kesadaran diri mengalami luka batin, kemauan dan upaya untuk sembuh. Dave Pelzer buktinya. Ia berhasil mengelola emosi dan kesadarannya sehingga memiliki kemampuan untuk memaafkan. Dengan demikian ia berhasil membebaskan dirinya dari rasa sakit yang menahun. Bukti lain adalah gadis (NN) yang diceritakan Sr. Maria Felicia. Setelah NN didoakan penyembuhan batin pada masa dalam kandungan dan diterapi untuk memaafkan, dia mengatakan bahwa ada suatu dalam batinnya yang lepas dari dirinya. Suatu ketenangan dan ketenteraman yang dia rasakan. Hidup terasa menjadi ringan dan tiada beban. Semua tugas-tugas dapat dilakukan dengan ringan dan cepat selesai. Demikian juga yang dialami Ignatius Sunandar. Ia yakin untuk bisa membebaskan diri dari rasa bersalah adalah dengan memaafkan, tidak ada cara lain. Karena itu, ia memaafkan (berdamai dengan) dirinya sendiri, minta maaf kepada orang yang telah disakitinya dan menerima maaf darinya. Memaafkan itu merupakan jalan penyembuhan. Sebab hanya dengan cara memaafkan, ia (dan orang yang telah disakiti, begitu keyakinannya) boleh merasa mendapat kebebasan dari belenggu luka-luka batin yang menimbulkan kepedihan dan kesakitan itu.

\section{DAFTAR PUSTAKA}

Augsburger, D. (1981). Caring enough to not forgive. Scottsdale, AZ: Herald.

Brandsma, J. M. (1982). Forgiveness: A dynamic, theological and therapeutic analysis. Pastoral Psychology, 31(1) p. 40-50., 31(1), 40-50.

Coyle, C. T., \& Enright, R. D. (1997). Forgiveness intervention with postabortion men. Journal of Consulting and Clinical Psychology, 65, 1042-1046.

Enright, R.D., Freedman, S., \& Rique, J. (1998). The psychology of interpersonal forgiveness. In R.D. Enright \& J. North (Eds.), Exploring forgiveness (pp. 46-62.) Madison, WI: University of Wisconsin Press

Enright, R. \& The Human Development Study Group (1991). The moral development of forgiveness. In W. Kurtines, \& J. Gewirtz (Ed.), Handbook of Moral Behavior and Development (pp. 123-152). Hillsdale, NJ: Erlbaum.

en.wikipedia.org/wiki/Dave_Pelzer

Felicia, Maria Sr. P.Karm. (2010); dalam www.carmelia.net/...penyembuhan-luka-batin.

Fitzgibbons, R. P. (1986). The cognitive and emotive uses of forgiveness in the treatment of anger. Psychotherapy, 23(4), 629-633.

Ignatius Sunandar (2010); dalam filsafat.kompasiana.com/.../forgiving-awal-penyembuhan-luka-batin.

Mawan (2009); dalam gkiperniagaan.org/.../penyembuhan-luka-batin. 
McCullough, M. E., Worthington, E. L., Jr., \& Rachal, K. C. (1997). Interpersonal forgiving in close relationships. Journal of Personality and Social Psychology, 73, 321-336.

McCullough, M. E. (2000). Forgiveness as human strength: Theory, measurement, and links to wellbeing. Journal of Social and Clinical Psychology, 19, 43-55.

McCullough, M. E., Bellah, C. G., Kilpatrick, S. D., \& Johnson, J. L. (2001). Vengefulness: Relationships with forgiveness, rumination, well-being, and the Big Five. Personality and Social Psychology Bulletin, 27, 601-610.

Worthington, Everett L (1998). "The pyramid model of forgiveness: Some interdisciplinary speculations about unforgiveness and the promotion of forgiveness." In Dimensions of forgiveness: Psychological research \& theological forgiveness, ed. Everett L. Worthington, Jr., 107-138. With a preface and an introduction by Everett L. Worthington, Jr. Philadelphia: Templeton Foundation Press.

Worthington, E. L., Jr. (1998). An empathy-humility-commitment model of forgiveness applied within family dyads. Journal of Family Therapy, 20, 59-76.

Worthington, E.L., Wade, N.G. (1999) . The Psychology of unforgiveness and forgiveness and implication for clinical practice.Journal of Social and Clinical Psychology, 18/4, 385-418.

Pargament, K.L. (1997). The Psychology of Religion and Coping. New York: The Guilford Press.

Payne, L. (1991). Restoring the Christian Soul: Overcoming barriers to completion in Christ through healing prayer. Grand Rapids, MI: Baker Books.

Pelzer, Dave (2003). A Man Named Dave (terj.). Jakarta: Gramedia.

Pelzer, Dave (2003).The Lost Boy (terj.). Jakarta: Gramedia.

Pelzer, Dave (2003). A Child Called “It” (terj.). Jakarta: Gramedia.

Schimmel, S. (2002). Wounds Not Healed by Time: The power of repentance and forgiveness. New York: Oxford Univ. Press.

Shapiro, D. L. (1991). The effetcs of explanations on negative reactions to deceit. Administrative Science Quarterly, 36, 614-630.

Spring, J. A. (2004). How can I forgive you?: The courage to forgive, the freedom not to. New York: HarperCollins.

Theresianne, Sasraningrat Sr. Dra. (2006). Memahami Luka-luka Batin (makalah). 